DOI: 10.20472/EFC.2018.010.002

\author{
MAJED ALHARTHI \\ King Abdulaziz University, Saudi Arabia
}

\title{
DETERMINANTS OF FOREIGN DIRECT INVESTMENT IN GULF COOPERATION COUNCIL (GCC) REGION
}

\begin{abstract}
:
This study aims to find the main determinants of foreign direct investment (FDI) in Gulf Cooperation Council (GCC) Region using a panel data from 1996-2016. The GCC region is facing new economic reforms as a result of low oil prices when oil is the main product of GDP in GCC. In addition, GCC impose tax in 2018 that would affect economy negatively due to lowering in purchase power. Based on lower prices of oil, Saudi Arabia released a plan called Vision 2030. This vision was announced in 26 April 2016 by Crown Prince Mohammad bin Salman. The main reason behind this vision is to diversify economy. The FDI is one of the most important indicators to realize this diversity of economy. In this study, the data was collected through the United Nations Conference of Trade and Development, World Bank and International Monetary Fund (IMF) databases. The data was analyzed through fixed-effects model and random-effects model. The GDP is found to have a significant and positive impact on FDI. The Arab Spring affected the FDI negatively and significantly through the period of the study.
\end{abstract}

\section{Keywords:}

foreign direct investment; Gulf Cooperation Council; Vision 2030 


\section{Introduction}

The economies of Gulf Cooperation Council (GCC) countries (that including Bahrain, Kuwait, Oman, Qatar, Saudi Arabia, and the United Arab Emirates ([UAE]) are mainly depending on oil sector. Recently, the oil prices have dropped sharply due to a higher supply than demand. As a result, the economies of the GCC have struggled to recover. In 2016, the GCC policy makers strictly considered to diversify their economies. One of the main plans to diversify the economies of GCC is to attract foreign direct investment (FDI). The idea of diversifying the economy started on the 26th April 2016 from the Crown Prince of the Kingdom of Saudi Arabia, Mohammed bin Salman, announced KSA Vision 2030. The main goals of the Vision are to reduce the dependency on oil and to concentrate on non-oil industry such as FDI (KSA Vision 2030, 2018). Focusing on the determinants of FDI would help policy makers to discover the significant positive and negative indicators. The positive indicators help enhancing the growth of FDI while, the negative indices warn policy makers from dealing with negative indicators. Many recent studies focused on FDI such as Elheddad (2018) on GCC region and Kayalvizhi and Thenmozhi (2018) on emerging countries. There are many opportunities that GCC can develop in the region such as attracting foreign companies that can build their industries (factories). On the contrary, many challenges can face the GCC countries such as political conflict in the area of the Middle East. However, this study includes several contributions to the field of the study as (1) limited numbers of studies have concentrated on the GCC region. (2) The data covers the period of 1996-2016 which considered being extensive and recent data. (3) This study contributes in showing the effect of Arab Spring (Arab revolutions) on the FDI. This study attempts to find the significant positive and negative determinants of FDI in GCC region through the period of 1996-2016. The objective of this study is to answer the following questions:

Q1: What are the significant and positive determinants of FDI in GCC region?

Q2: What are the significant and negative determinants of FDI in GCC region?

The statistical methods to examine the relationship between FDI and its determinants are fixed-effects model (FEM) and random effects-model (REM) following Bengoa and Sanchez-Robles (2003) and Kumari and Sharma (2017). The paper is organized as follows: part 2 presents the literature review. Part 3 shows the data and methodology. Part 4 discusses the empirical results. Finally, part 5 illustrates the summary of the study. 


\section{Literature review and hypotheses formulation}

\subsection{Literature review}

Some studies have examined the determinants of FDI in the Middle Eastern and North African region but lack of studies have concentrated on the GCC area. This section explains the main recent studies on FDI.

Elheddad (2018) tested the indicators of FDI for GCC countries (Bahrain, Kuwait, Oman, Qatar, Saudi Arabia, and the United Arab Emirates ([UAE]) during the period 1980-2013. Statistically, fixed-effects model (FEM), random-effects model (REM) and generalized method of moments (GMM) regression have been used in this study. The main results showed that the gross domestic production (GDP) per capita was highly important to enhance FDI. This means that higher production would attract more investing in GCC (similar to Okafor et al., 2017). On the other side, inflation affected the FDI significantly and negatively. The inflation in this case discourages companies and countries from investing in GCC (the same result of Adhikary, 2017). In this study, the political instability and corruption have insignificant impact on FDI in GCC countries.

Mina (2009) focused also on the FDI of GCC countries for the period of 1984-2002. The generalized least square (GLS) and ordinary least square (OLS) have been used to identify the indices of FDI. The relationship between FDI and GDP was significant and positive, which means that higher economic development led to more foreign investments. Expensive studies approve the same result like the studies of Aziz and Mishra (2016) and Rashid et al. (2017). In addition, imports volume had a positive effect on FDI. Moreover, higher oil prices encouraged foreign investors to operate their businesses in GCC region.

Focusing on MENA area, Salem and Baum (2016) examined the factors of FDI for 8 countries in MENA region over the period 2003-2009. They used Tobit model to find the correlations between FDI and the independent variables. The findings suggest that unemployment rate led to higher FDI. This result is inconsistent with ÖzkanGünay (2011) finding that proposed a significant and negative association between unemployment and FDI. According to country governance indicators, regulatory quality impacted FDI significantly and positively. Overall, the variables of control of corruption, voice and accountability, political stability, government effectiveness and rule of law found to be insignificant with FDI.

Helmy (2013) also focused on 21 MENA countries to identify the factors of FDI through the period 1970-2009. Helmy (2013) employed FEM, GLS and GMM to test the indicators of FDI. This study concludes that the GDP per capita supported FDI 
significantly and positively. In contrast, inflation rates affected FDI significantly and negatively.

The conclusion of the literature review explains that the most studies have a significant and positive correlation between GDP and FDI. Additionally, majority of studies concluded that inflation impacted FDI significantly and negatively.

\subsection{Hypotheses formulation}

Following the literature, this study examines the correlation between FDI and GDP, GDP per capita, inflation, unemployment, control of corruption, political instability, rule of law, voice and accountability, global financial crisis (GFC) and Arab Spring (contribution to the field). These hypotheses can be formulated as following:

1. GDP: The majority of the recent studies confirmed that higher GDP values led to more FDI attractions (see Cheng et al., 2017; Fan et al., 2016). This means that economic development is strongly encourage companies to invest abroad. Based on the researcher knowledge, lack of studies approved a negative correlation between FDI and GDP. However, the first hypothesis is:

\section{H1: GDP affects FDI in GCC region significantly}

2. GDP per capita: FDI flows increasing due to higher individual incomes and wealth lead to larger sales and higher returns to investors. Comprehensive studies claimed that the relationship between FDI and GDP per capita is significant and positive (e.g. Cleeve et al., 2015; Okafor et al., 2017). Few studies proved the opposite result (see Dutt et al., 2017). Based on this, the second hypothesis is:

\section{H2: GDP per capita affects FDI in GCC region significantly}

3. Inflation: Effective Investors in general avoid higher costs and prices. This means that higher inflation would discourage many investors to operate their businesses abroad. According to the literature review, most researchers argued that inflation impact FDI significantly and negatively (similar to Helmy, 2013; Kayalvizhi \& Thenmozhi, 2018). Whereas, few studies approved that inflation support FDI positively (consistent to the study of Aziz \& Mishra, 2016). In this study, the third hypothesis is:

\section{H3: Inflation affects FDI in GCC region significantly}

4. Unemployment: The unemployment growth discourages investors to build their businesses due to lower purchase power of individual which results to reduce returns. 
Özkan-Günay's (2011) results claimed that grater unemployment rates decreased FDI significantly. This finding contradicts with Salem and Baum (2016) who approved a significant and positive association between FDI and unemployment growth. Thus, the fourth hypothesis is:

\section{H4: Unemployment affects FDI in GCC region significantly}

5. Control of corruption. The higher control of corruption means better government laws effectiveness. In the most studies in the literature, the FDI increases as a result of greater control of corruption (see Kayalvizhi \& Thenmozhi, 2018; Okafor et al., 2017). Few studies confirm insignificant correlation between FDI and control of corruption (Salem \& Baum, 2016). The fifth hypothesis however is:

\section{H5: Control of corruption affects FDI in GCC region significantly}

6. Political instability. The political instability measures the perceptions of the likelihood of political instability or politically motivated violence, including terrorism. Elshamy (2015) and Kayalvizhi and Thenmozhi (2018) approved a significant and positive correlation between FDI and political stability. In contrast, Fan et al. (2016) confirmed that the association between FDI and political stability was significant and negative. Based on this, the sixth hypothesis is:

H6: Political instability affects FDI in GCC region significantly

7. Rule of law. This variable reflects the strength of abiding of laws in a country such as contract enforcement and property rights. Kayalvizhi and Thenmozhi (2018) argued that higher rates of rule of law led to decreasing FDI. Moreover, Salem and Baum (2016) found insignificant correlation between rule of law and FDI. This study examines the relationship between FDI and rule of law. The seventh hypothesis can be formulated as:

\section{H7: Rule of law affects FDI in GCC region significantly}

8. Voice and accountability. This factor represents the percentage of perceptions in terms of the ability of citizens for selecting their governments, freedom of expression, freedom of association and free media. Limited studies focused on examining the correlation between FDI and voice and accountability. For example, Kayalvizhi and Thenmozhi (2018) and Salem and Baum (2016) found insignificant associations between FDI and voice and accountability. The eighth hypothesis is: 
H8: Voice and accountability affects FDI in GCC region significantly

9. Global financial crisis (GFC). Several studies approved that FDI was decreasing during the period of GFC (Avioutskii \& Tensaout, 2016; Saini \& Singhania, 2018). On the other side, few studies provided that FDI was negatively affected during the GFC times (Adhikary, 2017). Some researches confirmed no impact on FDI through GFC period (Aziz \& Mishra, 2016; Vadlamannati et al., 2018). The hypothesis of GFC is:

H9: GFC affects FDI in GCC region significantly

10. Arab Spring. In 2011, most economies in the MENA region were badly affected by the political instability in the area (Arabic Revelations). This study examines the impact of Arab Spring on FDI in GCC region through the following hypothesis:

\section{H10: Arab Spring affects FDI in GCC region significantly}

\section{Methodology}

\subsection{Data description}

The data in this study was collected from the databases of United Nations Conference on Trade and Development (UNCTAD), World Bank and International Monetary Fund (IMF). The data covers the period of 1996-2016 for GCC countries that including Bahrain, Kuwait, Oman, Qatar, Saudi Arabia, and the United Arab Emirates (UAE). The dependent variable is FDI and the independent variables are GDP, GDP per capita, inflation, unemployment, control of corruption, political stability, rule of law, voice and accountability, global financial crisis (GFC) and Arab Spring. Table 1 explains in details the statistics summary of dependent and independent variables for GCC countries for the period 1996-2016.

\subsection{Regression of FDI}

The data is analyzed through statistical models (using STATA 15 software) as fixedeffects model and random-effect model (Kumari \& Sharma, 2017). The regression can be formulated as: 
$F D I=\alpha+\beta_{1} G D P+\beta_{2}$ GDPP $+\beta_{3}$ INFLATION $+\beta_{4}$ UNEMPLOYMENT $+\beta_{5}$ CCORRUPTION + $\beta_{6}$ PSTABILITY $+\beta_{7} R L A W+\beta_{8}$ VACCOUNTABILITY $+\beta_{9}$ GFC $+\beta_{10}$ ASPRING + $\varepsilon \ldots \ldots \ldots \ldots \ldots \ldots \ldots(1)$

Where, $F D I$ is the natural logarithm of FDI; GDP represents the natural logarithm of GDP; GDDP denotes the natural logarithm of GDP per capita; INFLATION is the percentage of interest rates; UNEMPLOYMENT describes the percentage of unemployment; CCORRUPTION is control of corruption percentage; PSTABILITY is the rate of political stability; $R L A W$ explains rule of law percentage; VACCOUNTABILITY denotes the rate of voice and accountability; GFC is the dummy of global financial crisis period; ASPRING is the dummy of Arab Spring period.

Before analyzing the data, the correlation matrix has to be tested to insure that the data do not have multicollinearity. Table 2 indicates that all correlation values are lower than $70 \%$.

Table 1. Variable definitions and summary statistics for GCC countries

\begin{tabular}{|c|c|c|c|c|c|c|c|}
\hline \multirow[b]{2}{*}{ Variables } & \multirow[b]{2}{*}{ Definition } & \multicolumn{5}{|c|}{ Statistics } & \multirow[b]{2}{*}{$\begin{array}{l}\text { Expectec } \\
\text { Sign }\end{array}$} \\
\hline & & $\begin{array}{c}\mathrm{O} \\
\mathrm{bs}\end{array}$ & $\begin{array}{c}\text { Mea } \\
\mathrm{n}\end{array}$ & S.D & Min & $\begin{array}{c}\mathrm{Ma} \\
\mathrm{x}\end{array}$ & \\
\hline \multicolumn{8}{|c|}{ Dependent variable } \\
\hline FDI & $\log ($ FDI) & $\begin{array}{c}12 \\
6 \\
\end{array}$ & $\begin{array}{c}6.63 \\
9\end{array}$ & $\begin{array}{l}1.9 \\
97 \\
\end{array}$ & $\begin{array}{c}1.2 \\
9 \\
\end{array}$ & $\begin{array}{l}10 . \\
58 \\
\end{array}$ & ----- \\
\hline \multicolumn{8}{|c|}{ Independent variables } \\
\hline GDP & $\log (G D P)$ & $\begin{array}{c}12 \\
6\end{array}$ & $\begin{array}{c}24.9 \\
92\end{array}$ & $\begin{array}{l}1.2 \\
56\end{array}$ & $\begin{array}{l}22 . \\
53\end{array}$ & $\begin{array}{l}27 . \\
35\end{array}$ & + \\
\hline GDP per capita & Log (GDP per capita) & $\begin{array}{c}12 \\
6 \\
\end{array}$ & $\begin{array}{c}10.0 \\
38\end{array}$ & $\begin{array}{l}0.6 \\
41 \\
\end{array}$ & $\begin{array}{c}8.7 \\
4 \\
\end{array}$ & $\begin{array}{l}11 . \\
39\end{array}$ & + \\
\hline Inflation & Inflation rates & $\begin{array}{c}12 \\
6\end{array}$ & $\begin{array}{c}0.06 \\
3\end{array}$ & $\begin{array}{l}0.1 \\
62\end{array}$ & $\begin{array}{c}- \\
0.0 \\
5\end{array}$ & $\begin{array}{l}1.5 \\
5\end{array}$ & - \\
\hline Unemployment & $\begin{array}{l}\% \text {, higher percentage indicates higher } \\
\text { unemployment }\end{array}$ & $\begin{array}{c}12 \\
6\end{array}$ & $\begin{array}{c}0.05 \\
8\end{array}$ & $\begin{array}{l}0.0 \\
60\end{array}$ & $\begin{array}{c}0.0 \\
0\end{array}$ & $\begin{array}{c}0.2 \\
0\end{array}$ & - \\
\hline $\begin{array}{l}\text { Control of } \\
\text { corruption }\end{array}$ & $\begin{array}{l}\% \text {, higher percentage indicates higher } \\
\text { control of corruption }\end{array}$ & $\begin{array}{c}12 \\
6 \\
\end{array}$ & $\begin{array}{c}0.68 \\
4\end{array}$ & $\begin{array}{r}0.1 \\
05 \\
\end{array}$ & $\begin{array}{c}0.4 \\
8\end{array}$ & $\begin{array}{c}0.9 \\
1\end{array}$ & + \\
\hline Political stability & $\begin{array}{l}\%, \text { higher percentage indicates higher } \\
\text { political instability }\end{array}$ & $\begin{array}{c}12 \\
6\end{array}$ & $\begin{array}{c}0.60 \\
4\end{array}$ & $\begin{array}{c}0.2 \\
10\end{array}$ & $\begin{array}{c}0.0 \\
9\end{array}$ & $\begin{array}{c}0.9 \\
2\end{array}$ & - \\
\hline Rule of law & $\begin{array}{l}\% \text {, higher percentage indicates higher rule } \\
\text { of law }\end{array}$ & $\begin{array}{c}12 \\
6\end{array}$ & $\begin{array}{c}0.64 \\
9\end{array}$ & $\begin{array}{l}0.0 \\
66\end{array}$ & $\begin{array}{c}0.4 \\
8\end{array}$ & $\begin{array}{c}0.8 \\
0\end{array}$ & + \\
\hline $\begin{array}{l}\text { Voice and } \\
\text { accountability }\end{array}$ & $\begin{array}{l}\%, \text { higher percentage indicates higher } \\
\text { voice and accountability }\end{array}$ & $\begin{array}{c}12 \\
6\end{array}$ & $\begin{array}{c}0.21 \\
8\end{array}$ & $\begin{array}{l}0.1 \\
03\end{array}$ & $\begin{array}{c}0.0 \\
2\end{array}$ & $\begin{array}{c}0.4 \\
2\end{array}$ & + \\
\hline $\begin{array}{l}\text { Global financial } \\
\text { crisis }\end{array}$ & $\begin{array}{l}\text { Dummy = } 1 \text { for the period 2007-2009, } \\
\text { otherwise zero }\end{array}$ & $\begin{array}{c}12 \\
6\end{array}$ & $\begin{array}{c}0.14 \\
3\end{array}$ & $\begin{array}{l}0.3 \\
51\end{array}$ & 0 & 1 & - \\
\hline Arab Spring & $\begin{array}{l}\text { Dummy = } 1 \text { for the period 2011-2016, } \\
\text { otherwise zero }\end{array}$ & $\begin{array}{c}12 \\
6 \\
\end{array}$ & $\begin{array}{c}0.28 \\
6\end{array}$ & $\begin{array}{l}0.4 \\
54 \\
\end{array}$ & 0 & 1 & - \\
\hline
\end{tabular}

Sources: UNCTAD (2018), World Bank (2018) and IMF (2018) 
Table 2. Correlation matrix for variables

\begin{tabular}{|c|c|c|c|c|c|c|c|c|c|c|}
\hline Correlation Matrix & (1) & (2) & (3) & (4) & (5) & (6) & (7) & (8) & (9) & $\begin{array}{l}(1 \\
0)\end{array}$ \\
\hline (1) GDP & 1 & & & & & & & & & \\
\hline (2) GDP per capita & $\begin{array}{c}0.406 \\
8\end{array}$ & 1 & & & & & & & & \\
\hline (3)Inflation & $\begin{array}{c}- \\
0.199 \\
3\end{array}$ & $\begin{array}{c}- \\
0.285 \\
4\end{array}$ & 1 & & & & & & & \\
\hline (3) Unemployment & $\begin{array}{c}- \\
0.273 \\
5\end{array}$ & $\begin{array}{c}- \\
0.565 \\
2\end{array}$ & $\begin{array}{c}0.43 \\
82\end{array}$ & 1 & & & & & & \\
\hline $\begin{array}{l}\text { (4) Control of } \\
\text { corruption }\end{array}$ & $\begin{array}{c}- \\
0.116 \\
7\end{array}$ & $\begin{array}{c}0.376 \\
7\end{array}$ & $\begin{array}{c}0.14 \\
72\end{array}$ & $\begin{array}{c}- \\
0.026 \\
5\end{array}$ & 1 & & & & & \\
\hline (5) Political stability & $\overline{-}$ & $\begin{array}{c}0.315 \\
6\end{array}$ & $\begin{array}{c}0.19 \\
5\end{array}$ & $\begin{array}{c}0.189 \\
9\end{array}$ & $\begin{array}{c}0.619 \\
3\end{array}$ & 1 & & & & \\
\hline (6) Rule of law & $\begin{array}{c}- \\
0.044 \\
2\end{array}$ & $\begin{array}{c}0.501 \\
3\end{array}$ & $\begin{array}{c}0.04 \\
38\end{array}$ & $\begin{array}{c}- \\
0.113 \\
5\end{array}$ & $\begin{array}{c}0.648 \\
4\end{array}$ & $\begin{array}{c}0.487 \\
5\end{array}$ & 1 & & & \\
\hline $\begin{array}{l}\text { (7) Voice and } \\
\text { accountability }\end{array}$ & $0 .-$ & $\begin{array}{c}0.188 \\
3\end{array}$ & $\begin{array}{c}0.06 \\
72\end{array}$ & $\begin{array}{c}0.119 \\
3\end{array}$ & $\begin{array}{c}0.387 \\
2\end{array}$ & $\begin{array}{c}0.466 \\
8\end{array}$ & $\begin{array}{c}0.410 \\
3\end{array}$ & 1 & & \\
\hline $\begin{array}{l}\text { (8) Global financial } \\
\text { crisis }\end{array}$ & $\begin{array}{c}0.138 \\
7\end{array}$ & $\begin{array}{c}0.190 \\
1\end{array}$ & $\begin{array}{c}0.00 \\
7\end{array}$ & $\begin{array}{c}0.005 \\
3\end{array}$ & $\begin{array}{c}0.058 \\
2\end{array}$ & $\begin{array}{c}0.029 \\
9\end{array}$ & $\begin{array}{c}- \\
0.005 \\
9\end{array}$ & $\begin{array}{c}- \\
0.063 \\
2\end{array}$ & 1 & \\
\hline (8) Arab Spring & $\begin{array}{c}0.400 \\
4\end{array}$ & $\begin{array}{c}0.368 \\
8\end{array}$ & $\begin{array}{c}- \\
0.14 \\
5\end{array}$ & $\begin{array}{c}- \\
0.094 \\
8\end{array}$ & $\begin{array}{c}- \\
0.072 \\
6\end{array}$ & $\begin{array}{c}- \\
0.223 \\
1\end{array}$ & $\begin{array}{c}0.196 \\
7\end{array}$ & $\begin{array}{c}- \\
0.322 \\
4\end{array}$ & $\begin{array}{c}- \\
0.258 \\
2\end{array}$ & 1 \\
\hline
\end{tabular}




\section{Results and Discussion}

Table 3 shows the findings of the significant positive and negative determinants of FDI in GCC countries for the period 1996-2016. There are significant correlations between FDI and GDP, GDP per capita and unemployment. On the contrary, political stability, rule of law, voice and accountability and Arab Spring have negative signs.

Table 3. FEM and REM findings for GCC countries

\begin{tabular}{|c|c|c|}
\hline Regression & FEM & REM \\
\hline Dependent Variable & FDI & FDI \\
\hline \multicolumn{3}{|l|}{ Independent Variables } \\
\hline \multirow{2}{*}{$(\mathrm{H} 1) \mathrm{GDP}$} & 0.103 & $0.298^{*}$ \\
\hline & $(0.18)$ & $(2.33)$ \\
\hline \multirow{2}{*}{ (H2) GDP per capita } & $2.777^{\star * \star}$ & $2.802^{\star \star \star}$ \\
\hline & $(3.41)$ & $(7.43)$ \\
\hline \multirow{2}{*}{ (H3) Inflation } & -0.0532 & -0.572 \\
\hline & $(-0.08)$ & $(-0.73)$ \\
\hline \multirow{2}{*}{ (H4) Unemployment } & $40.98^{* \star \star}$ & $14.47^{* \star *}$ \\
\hline & $(5.49)$ & $(4.57)$ \\
\hline \multirow{2}{*}{ (H5) Control of corruption } & 1.014 & 2.744 \\
\hline & $(0.65)$ & $(1.72)$ \\
\hline \multirow{2}{*}{ (H6) Political instability } & $-3.900^{* *}$ & $-3.064^{* \star}$ \\
\hline & $(-2.93)$ & $(-3.27)$ \\
\hline \multirow[b]{2}{*}{ (H7) Rule of law } & -4.238 & $-6.440^{*}$ \\
\hline & $(-1.68)$ & $(-2.49)$ \\
\hline \multirow{2}{*}{ (H8) Voice and accountability } & $-6.756^{*}$ & $-8.539^{* \star}$ \\
\hline & $(-2.24)$ & $(-5.21)$ \\
\hline \multirow{2}{*}{ (H9) GFC } & 0.236 & -0.128 \\
\hline & $(0.67)$ & $(-0.32)$ \\
\hline \multirow{2}{*}{ (H10) Arab Spring } & -0.517 & $-1.130^{* *}$ \\
\hline & $(-1.18)$ & $(-2.79)$ \\
\hline \multirow[b]{2}{*}{ _cons } & $-20.18^{*}$ & $-23.38^{* *}$ \\
\hline & $(-2.56)$ & $(-5.37)$ \\
\hline$N$ & 126 & 126 \\
\hline$R^{2}$ & 0.6716 & 0.6100 \\
\hline
\end{tabular}

Notes: $t$ statistics in parentheses, ${ }^{*} p<0.05,{ }^{\star *} p<0.01,{ }^{\star \star *} p<0.001$

H1: GDP. Table 3 shows that the relationship between FDI and GDP is positive and significant. This result complies with the expectation as investors prefer to build their businesses in developed economies and larger-sized markets. This finding is consistent with comprehensive number of studies (Adhikary, 2017; Avioutskii \& Tensaout, 2016; Cheng et al., 2017; Rashid et al., 2017). Some studies found no correlation between FDI and GDP (Mina, 2007). 
H2: GDP per capita. As expected, GDP per capita affected FDI significantly and positively. This means that higher real wages of GCC countries attract foreign investing. The majority of the recent studies approved the same point (Cleeve et al. 2015; Daniele \& Marani 2011; Gamboa 2013; Okafor et al., 2017). Limited studies in the literature confirmed a negative association between FDI and GDP per capita (Dutt et al., 2017).

H4: Unemployment: the growth of unemployment is found significantly and positively influencing FDI. This contradicts with the expectation (hypothesis). This means that unemployment rate did not stop foreign investors from investing in GCC through the period 1996-2016. Salem and Baum's (2016) results reported the same conclusion while, Özkan-Günay (2011) approved a significant and negative correlation between unemployment rates and FDI. Ramos and Ashby (2013) however found insignificant association between unemployment rates and FDI.

H6: Political stability. As expected, higher political instability rates are significantly discouraging foreign investors from operating their businesses in GCC countries. According to the literature, Fan et al. (2016) pointed to a significant and negative relationship between political instability and FDI in 69 countries. On the other side, Rashid et al. (2017) proposed a significant and positive association between political instability and FDI in 15 Asian countries.

H7: Rule of law. Regarding the FEM, the sign of coefficient for rule of law is negative and it is significantly impacted FDI. On other words, poor quality of the implementation of rules and freedom of expression led to better FDI. This completely went against the initial and expected hypothesis of rule of law. Kayalvizhi and Thenmozhi (2018) have the same result while, Salem and Baum (2016) found insignificant correlation between rule of law and FDI.

H8: Voice and accountability. Based on the results of FEM and REM, more FDI found in countries with weaker ability of citizens for selecting their governments, freedom of expression, freedom of association and free media. The results of Kayalvizhi and Thenmozhi (2018) and Salem and Baum (2016) reported no correlation between FDI and voice and accountability.

H10: Arab Spring. Based on REM's results, the foreign direct investment in GCC countries was affected significantly and negatively during the Arab Spring period. This finding is consistent with prediction (hypothesis). 


\section{Conclusion}

The main aim of this study was finding the determinants of foreign direct investment (FDI) in GCC countries over the period 1996-2016. The data was collected through the United Nations Conference of Trade and Development, World Bank and IMF databases. However, the statistical models are fixed-effects model (FEM) and random-effects model (REM). The main results suggested that the GDP had a significant and positive impact on FDI. Moreover, FDI influenced significantly and negatively through the period of Arab Spring.

This study helps the economic and financial policymakers to attract foreign direct investment. In addition, foreign investors can find the efficiency of investing in GCC region.

The limitation of this study is the non-availability of the year 2017 (not available in databases).

Further researches can cover the updated periods until 2017 or 2018. In addition, more countries can be tested. Moreover, other models and variables can be employed in the future studies.

\section{References}

Adhikary, B.K. (2017). Factors influencing foreign direct investment in South Asian economies: A comparative analysis. South Asian Journal of Business Studies, 6(1), 8-37.

Avioutskii, V., \& Tensaout, M. (2016). Does politics matter? Partisan FDI in Central and Eastern Europe. Multinational Business Review, 24(4), 375-398.

Aziz, O.G., \& Mishra, A.V. (2016). Determinants of FDI inflows to Arab economies. The Journal of International Trade \& Economic Development, 25(3), 325-256.

Bengoa, M., \& Sanchez-Robles, B. (2003). Foreign direct investment, economic freedom and growth: new evidence from Latin America. European Journal of Political Economy, 19, 529-545.

Cheng, S., Lin, K., \& Simmons, R. (2017). A city-level analysis of the distribution of FDI within China. Journal of Chinese Economic and Foreign Trade Studies, 10(1), 2-18.

Cleeve, E.A., Debrah, Y., \& Yiheyis, Z. (2015). Human Capital and FDI Inflow: An Assessment of the African Case. World Development, 74, 1-14.

Daniele, V., \& Marani, U. (2011). Organized crime, the quality of local institutions and FDI in Italy: A panel data analysis. European Journal of Political Economy, 27, 132-142.

Dutta, N., Kar, S., \& Saha, S. (2017). Human capital and FDI: How does corruption affect the relationship?. Economic Analysis and Policy, 56, 126-134. 
Elheddad, M.M. (2018). What determines FDI inflow to MENA countries? Empirical study on Gulf countries: Sectoral level analysis. Research in International Business and Finance, 44, 332-339.

Elshamy, H.M. (2015). The economic determinants of Chinese foreign direct investment in Egypt. Journal of Chinese Economic and Foreign Trade Studies, 8(1), 20-26.

Fan, Z., Zhang, R., Liu, X., \& Pan, L. (2016). China's outward FDI efficiency along the Belt and Road: An application of stochastic frontier gravity model. China Agricultural Economic Review, 8(3), 455-479.

Gamboa, O.R.E. (2013). Foreign direct investment (FDI) determinants and spatial spillovers across Mexico's states. The Journal of International Trade \& Economic Development, 22(7), 993-1012.

Helmy, H.E. (2013). The impact of corruption on FDI: is MENA an exception?. International Review of Applied Economics, 27(4), 491-514.

International Monetary Fund (2018). Available: http://www.imf.org

Kayalvizhi, P.N., \& Thenmozhi M. (2018). Does quality of innovation, culture and governance drive FDI?: Evidence from emerging markets. Emerging Markets Review, 34, 175-191.

Kumari, R., \& Sharma, A.K. (2017). Determinants of foreign direct investment in developing countries: a panel data study. International Journal of Emerging Markets, 12(4), 658-682.

KSA Vision 2030 (2018). Available at: http://vision2030.gov.sa

Mina, W. (2007). The location determinants of FDI in the GCC countries. Journal of Multinational Financial Management, 17,336-348.

Mina, W. (2009). External commitment mechanisms, institutions, and FDI in GCC countries. Journal of International Financial Markets, Institutions \& Money, 19, 371-386.

Okafor, G., Piesse, J., \& Webster, A. (2017). FDI Determinants in Least Recipient Regions: The Case of Sub-Saharan Africa and MENA. African Development Review, 29(4), 589-600.

Özkan-Günay, E.N. (2011). Determinants of FDI Inflows and Policy Implications: A comparative Study for the Enlarged EU and Candidate Countries. Emerging Markets Finance and Trade, 47(4), 71-85.

Ramos, M.A., \& Ashby, N.J. (2013). Heterogeneous firm response to organized crime: Evidence from FDI in Mexico. Journal of International Management, 19, 176-194.

Rashid, M., Looi, X.H., \& Wong, S.J. (2017). Political stability and FDI in the most competitive Asia Pacific countries. Journal of Financial Economic Policy, 9(2), 140-155.

Saini, N., \& Singhania, M. (2018). Determinants of FDI in developed and developing countries: a quantitative analysis using GMM. Journal of Economic Studies, 42(2), 348-382.

Salem, M., \& Baum, A. (2016). Determinants of foreign direct real estate investment in selected MENA countries. Journal of Property Investment \& Finance, 34(2), 116-142.

United Nations Conference on Trade and Development (2018). Available: http://unctad.org 
Vadlamannati, K.C., Janz, N., \& Berntsen, Ø.I. (2018). Human Rights Shaming and FDI: Effects of the UN Human Rights Commission and Council. World Development, 104, 222-237.

World Bank (2018). Availab4le: https://www.worldbank.org 